\title{
Isolasi Metabolit Sekunder dari Ekstrak Etil Asetat Kulit Batang Meranti Rambai (Shorea acuminata Dyer)
}

\author{
Enda Mora, Septi Muharni, Emrizal, Rahayu Utami, dan Mella Silfia Andriani
}

Sekolah Tinggi Ilmu Farmasi, Riau

Korespondensi: Enda Mora

Email: bangendaapt@gmail.com

\begin{abstract}
ABSTRAK: Telah dilakukan isolasi dan pengujian sitotoksik ekstrak etil asetat kulit batang meranti rambai (Shorea acuminata Dyer). Ekstraksi dilakukan dengan maserasi bertingkat dan uji sitotoksik dengan metode Brine Shrimp Lethality Test (BSLT). Isolasi dilakukan dengan kromatografi kolom memakai sistem gradient dan diperoleh senyawa $\mathrm{D}_{1}$, berupa amorf berwarna putih sebanyak $18 \mathrm{mg}$ dengan titik leleh $280-282^{\circ} \mathrm{C}$. Berdasarkan hasil reaksi dengan reagen Liebermann-Buchard (yaitu warna orange kecoklatan) dan hasil karakterisasi dengan spektroskopi UV, IR, ${ }^{1} \mathrm{H}-\mathrm{RMI}$, dan ${ }^{13} \mathrm{C}$ RMI, maka dapat disimpulkan bahwa senyawa $\mathrm{D}_{1}$ termasuk golongan terpenoid. Dari hasil pengujian sitotoksik ekstrak etil asetat didapatkan nilai $\mathrm{LC}_{50}$ sebesar 3,68 ppm dan dapat dinyatakan bahwa ekstrak etil asetat kulit batang meranti rambai memiliki sifat sangat toksik terhadap kematian Artemia salina Leach.
\end{abstract}

Kata kunci: meranti rambai; Shorea acuminata Dyer; terpenoid; sitotoksik; BSLT

\begin{abstract}
Isolation and cytotoxicity test of ethyl acetate extract of the bark of Shorea acuminata Dyer (meranti rambai) and have been done. Extraction was carried out by gradually maceration and cytotoxicity test by Brine Shrimp Lethality Test (BSLT). Isolation was performed by column chromatography using gradient system and then compound of $D_{1}$ was obtained in the form of a white amorphous as much as 18 $\mathrm{mg}$ with a melting point of $280-282^{\circ} \mathrm{C}$. Based on the results of the reaction with the Liebermann-Buchard reagent (ie brownish orange color) and characterization by UV spectroscopy, $I R,{ }^{1} \mathrm{H}-\mathrm{NMR}$, and ${ }^{13} \mathrm{C}-\mathrm{NMR}$, it can be concluded that the compound of $D_{1}$ belonged to the terpenoids group. From the cytotoxicity test, it was found that ethyl acetate extract had $L C_{50}$ values of $3.68 \mathrm{ppm}$ and can be stated that the ethyl acetate extract of bark of meranti rambai is very toxic to the Artemia salina Leach.
\end{abstract}

Keywords: meranti rambai; Shorea acuminata Dyer; terpenoid; cytotoxicity; BSLT 


\section{Pendahuluan}

Pengobatan dengan menggunakan tumbuhan obat dipercaya lebih aman karena mempunyai efek samping yang lebih rendah dibandingkan dengan menggunakan obat sintetis [1]. Shorea adalah salah satu tumbuhan obat yang termasuk dalam famili Dipterocarpaceae. Tumbuhan ini merupakan kelompok tumbuhan tingkat tinggi yang tumbuh di hutan tropis yang tersebar di sebagian wilayah Indonesia terutama hutan Kalimantan dan Sumatera bagian timur [2].

Beberapa jenis Shorea telah diketahui memiliki aktivitas biologi yang menarik, misalnya Shorea acuminata Dyer. Dari tanaman ini telah diisolasi senyawa acuminatol dan oligomer resveratrol lainnya yang memiliki aktivitas sebagai antioksidan dengan nilai $\mathrm{IC}_{50} 0,84 \mu \mathrm{g} / \mathrm{ml}$ serta efek sitotoksik dengan nilai $\mathrm{LC}_{50} 161 \mu \mathrm{g} / \mathrm{ml}$ [3]. Contoh lain adalah Shorea leprosula Miq. Beberapa stilbenoid dari ekstrak aseton kulit batang Shorea leprosula memiliki aktivitas biologis sebagai antikanker, antihistamin, dan antibakteri [4]. Aktivitas antibakteri ekstrak kulit batang Shorea leprosula terhadap Eschericia coli masih

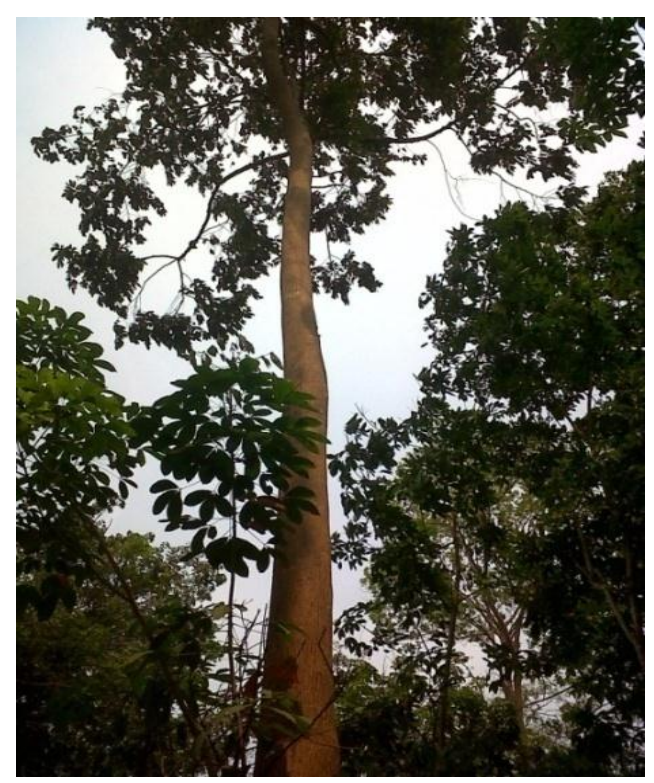

Gambar 1. Tumbuhan Shorea acuminata Dyer (meranti rambai) tergolong lemah dan sedang [5]. Dari fraksi etil asetat kelompok meranti merah lainnya (Shorea ovalis Kort) telah berhasil dikarakterisasi senyawa terpenoid berdasarkan data spektroskopi UV, IR, dan NMR [6]. Selain itu, oligostilbenoid dari ekstrak metanol kulit batang Shorea gibbosa juga telah diketahui berkhasiat sebagai anti kanker [7]. Isolat-isolat dari ekstrak aseton kulit batang Shorea assamica Dyer memiliki aktivitas sitotoksik terhadap sel murine leukemia P-388, dengan ni-

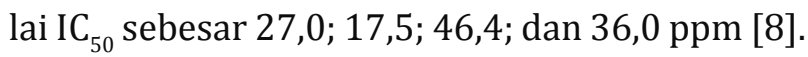
Fraksi etil asetat kulit batang Shorea singkawang (Miq) memiliki aktivitas antioksidan dengan nilai $\mathrm{EC}_{50}$ sebesar 82 ppm dan berdasarkan analisis menggunakan spektroskopi UV, IR, dan GC-MS serta penggunaan pereaksi warna menunjukkan bahwa isolate dari fraksi ini merupakan triterpenoid pentasiklik.

Shorea acuminata Dyer atau meranti rambai (Gambar 1 dan 2) tumbuh alami di daerah Kalimantan, Sumatera, Jawa, Nusa Tenggara, Bali, Sulawesi, dan Maluku. Sumatera menempati urutan kedua setelah Kalimantan dalam hal kekayaan jenis dan penyebaran jenis endemik di dunia. Dipterocarpaceae dapat dijumpai di hutan hu-

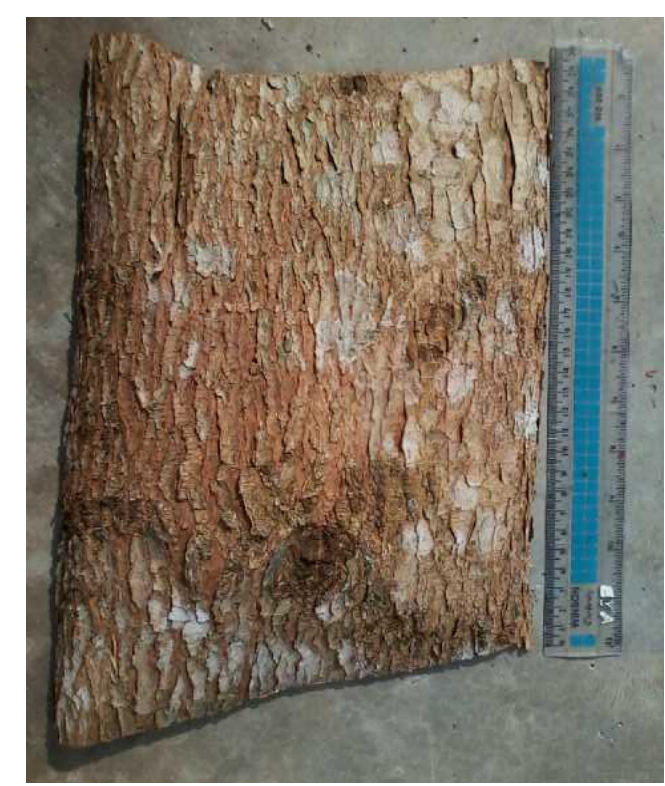

Gambar 2. Kulit batang meranti rambai 
jan dataran rendah mulai 0 hingga $500 \mathrm{~m}$ di atas permukaan laut, dengan rata-rata curah hujan 2000-3000 mm per tahun, basah dan kelembaban tinggi serta pada ketinggian mencapai 1750 $\mathrm{m}$ dari permukaan laut. Meranti pada umumnya tumbuh pada tipe tanah latosol, podsolik merah kuning dan podsolik kuning, dengan berbagai tingkat kesuburan tanah [9].

Shorea acuminata Dyer adalah salah satu spesies yang termasuk genus utama dari famili Dipterocarpaceae yang merupakan tanaman potensial. Tumbuhan ini mempunyai nilai ekonomi yang sangat tinggi, dan telah digunakan antara lain sebagai bahan baku bangunan, industri kayu lapis, industri PULP, dan kertas. Di sisi lain, famili Dipterocarpaceae menghasilkan berbagai jenis senyawa kimia seperti terpenoid, steroid, flavonoid, dan oligostilbenoid, yang memiliki berbagai aktivitas biologis seperti antitumor, anti HIV, antifungi, antioksidan, hepatoprotektif, kosmetika, dan fitoaleksin.

Berdasarkan informasi di atas, maka gagasan ini muncul untuk meneliti kandungan metabolit sekunder kulit batang meranti rambai yang bertujuan untuk mengisolasi metabolitnya dengan harapan dapat dilakukan uji aktivitas dan dikembangkan sebagai bakal bahan obat. Pada bagian batang, daun, dan biji tumbuhan Shorea diduga mengandung metabolit sekunder yang berfungsi sebagai antioksidan, antibakteri, antifungi, dan sitotoksik [8].

\section{Metode}

\subsection{Alat dan bahan}

Alat yang digunakan dalam penelitian ini adalah seperangkat alat destilasi, rotary evaporator, lumpang, neraca analitik, kolom kromatografi, plat KLT silika gel $\mathrm{GF}_{254}$, chamber, lampu UV penampak noda, vial, pipa kapiler, melting point apparatus, spektrofotometer UV-Vis, FTIR, dan RMI. Bahan tanaman yang digunakan dalam penelitian ini yaitu kulit batang meranti rambai (Shorea acuminata Dyer) yang diambil dari dae- rah Sungai Ara, Kecamatan Pelalawan, Kabupaten Pelalawan, Provinsi Riau dan determinasi tanaman dilakukan di Laboratorium Botani Jurusan FMIPA Universitas Riau. Bahan kimia meliputi $n$-heksan, etil asetat, metanol, aquades, asam asetat anhidrat, kloroform, amoniak, logam magnesium, larutan $\mathrm{FeCl}_{3}, \mathrm{HCl} 1 \%, \mathrm{H}_{2} \mathrm{SO}_{4} 2 \mathrm{~N}$, pereaksi Liebermann-Burchard, pereaksi Mayer, pereaksi anisaldehid, DMSO (dimetilsulfoksida) dan silika gel 60.

\subsection{Skrining fitokimia}

Uji pendahuluan kandungan metabolit sekunder dilakukan terhadap kulit batang meranti rambai. Sebanyak 5 g sampel dipotong sampai halus, lalu diekstraksi dengan etanol, kemudian pada ekstrak ini ditambahkan masing-masing 5 $\mathrm{ml}$ air suling dan kloroform lalu dikocok kuat dan dibiarkan beberapa saat sampai terbentuk dua lapisan. Lapisan air digunakan untuk uji senyawa flavonoid, fenolik, dan saponin sedangkan lapisan kloroform digunakan untuk uji senyawa terpenoid dan steroid. Untuk uji alkaloid, 5 g serbuk kulit batang meranti rambai ditambahkan $10 \mathrm{ml}$ kloroform, kemudian ditambahkan 10 ml larutan kloroform beramoniak 0,05 M, diaduk kemudian disaring. Ke dalam tabung reaksi ditambahkan 1 ml asam sulfat $2 \mathrm{~N}$, dikocok selama 2 menit, kemudian dibiarkan hingga terbentuk dua lapisan dan terjadi pemisahan. Lapisan asam (atas) diambil dan ditambahkan 1-2 tetes pereaksi Mayer. Jika terbentuk endapan putih dengan pereaksi Mayer menunjukkan hasil yang positif untuk alkaloid, atau dengan menggunakan pereaksi Dragendorff akan terbentuk warna jingga.

\subsection{Penyiapan ekstrak}

Kulit batang meranti rambai segar sebanyak 10,9 kg terlebih dahulu dibersihkan, lalu dirajang, kemudian dikeringanginkan selama satu bulan dan dihaluskan. Setelah itu sampel dimaserasi bertingkat yang dimulai dengan pelarut $n$-heksan, kemudian ampasnya dimaserasi kembali menggunakan etil asetat, masing-masing 
5 hari dengan 2 kali pengulangan. Setelah disaring, ekstrak etil asetat dipekatkan dengan rotary evaporator hingga kental, kemudian dilakukan uji KLT untuk melihat jumlah noktah atau komponen senyawa yang ada dalam ekstrak [10].

\subsection{Pemisahan dengan kromatografi kolom}

Pemisahan senyawa-senyawa yang ada di dalam ekstrak dilakukan dengan kromatografi kolom menggunakan silika gel 60. Pengisian kolom dilakukan dengan membuat bubur silika terlebih dahulu, lalu bubur silika dimasukkan ke dalam kolom dengan menggunakan corong, kemudian dielusi sampai kerapatan silika di dalam kolom maksimum. Ekstrak yang akan dipisahkan di-preadsorpsi dan dimasukkan ke dalam kolom. Kemudian dielusi dengan cara step gradien polarity menggunakan pelarut $n$-heksan, etil asetat, kemudian dengan metanol. Hasil pemisahan ditampung dalam botol vial dan diberi nomor [11].

Hasil pemisahan kromatografi kolom kemudian dilakukan KLT. Vial-vial yang akan diuji diambil secara acak setiap 5 vial, lalu masingmasing fraksi di totolkan pada plat yang telah diberi nomor sesuai dengan nomor vial kemudian dielusi dengan eluen yang sesuai sampai garis atas plat KLT, plat dikeluarkan dan dikeringkan. Untuk melihat noktah yang dihasilkan dilakukan dengan penyinaran lampu UV. Selanjutnya ditentukan Rf dari masing-masing noktah. Vial yang mempunyai harga Rf yang sama digabungkan menjadi satu fraksi. Setelah diperoleh hasil fraksi kolom kemudian dilakukan proses pemurnian senyawa dengan cara rekristalisasi.

\subsection{Karakterisasi}

Senyawa murni (kemurnian ditentukan dengan KLT dan pengujian titik leleh menggunakan melting point apparatus) yang diperoleh dari pemisahan dengan kromatografi kolom selanjutnya dilakukan elusidasi struktur menggunakan spektrofotometer UV-Vis, Infra merah (IR), dan spektroskopi resonansi magnetik inti (NMR) [12-14].

\subsection{Uji sitotoksik ekstrak etil asetat kulit batang meranti rambai dengan metode Brine Shrimp Lethality Test (BSLT)}

Kista udang Artemia salina diteteskan dalam wadah pembiakan yang berisi air laut dan telah dilengkapi dengan aerasi dan lampu, digunakan 48 jam setelah pembentukan larva. Vial uji dikalibrasi sebanyak $5 \mathrm{ml}$. Pengujian dilakukan dengan konsentrasi 100, 10, dan $1 \mu \mathrm{g} / \mathrm{ml}$. Sebanyak 40 mg sampel uji dilarutkan dalam $4 \mathrm{ml}$ etanol sehingga didapat larutan induk dengan konsentrasi $10000 \mu \mathrm{g} / \mathrm{ml}$. Dari larutan induk tersebut dipipet sebanyak 0,5 ml, ditambahkan etanol sampai $5 \mathrm{ml}$ dan diperoleh larutan dengan konsentrasi 1000 $\mu \mathrm{g} / \mathrm{ml}$, kemudian dilakukan pengenceran sampai didapat larutan dengan konsentrasi 100 dan 10 $\mu \mathrm{g} / \mathrm{ml}$. Tiap konsentrasi larutan uji dipipet 0,5 ml, dibiarkan pelarutnya menguap, dilarutkan kembali dengan $50 \mu \mathrm{l}$ DMSO, selanjutnya ditambahkan dengan air laut sampai hampir mencapai batas kalibrasi. Larva udang dimasukkan ke dalam masing-masing vial sebanyak 10 ekor, kemudian ditambahkan air laut beberapa tetes hingga batas kalibrasi $5 \mathrm{ml}$, dan didapat konsentrasi 100, 10, dan $1 \mu \mathrm{g} / \mathrm{ml}$ (masing- masing dibuat dalam 3 vial). Kematian larva udang diamati setelah 24 jam dan dari data yang dihasilkan kemudian dihitung nilai $\mathrm{LC}_{50}$ dengan metode kurva dan menggunakan tabel probit $[7,15]$.

\section{Hasil}

Dari 10,9 kg kulit batang segar meranti rambai diperoleh simplisia kering sebanyak 5,2 kg dan dari ekstraksi menggunakan pelarut etil asetat diperoleh ekstrak kental sebanyak 32,58 g. Hasil skrining fitokimia kulit batang meranti rambai menunjukkan adanya kandungan flavonoid, fenolik, saponin, dan terpenoid, sedangkan ekstrak etil asetat kulit menunjukkan adanya fenolik dan terpenoid.

Hasil pemisahan dari 6 g ekstrak kental etil asetat kulit batang meranti rambai dengan menggunakan kromatografi kolom diperoleh 331 vial. 


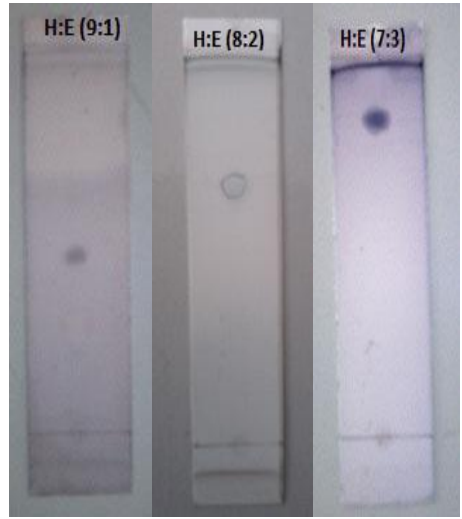

A $\quad$ B $\quad$ C

Gambar 3. Hasil KLT senyawa $\mathrm{D}_{1}$

Fase diam Silika gel $\mathrm{GF}_{254}$, eluen heksan:etil asetat dengan perbandingan 9:1 (A), 8:2 (B), dan 7:3 (C), penampak noda anisaldehid

Kemudian hasil yang diperoleh dilakukan pemeriksaan profil KLT lalu dilakukan penggabungan, dan didapatkan hasil 16 fraksi yaitu FA-FP dan diperoleh senyawa murni $\mathrm{D}_{1}$ (fraksi $\mathrm{D}$ vial 60-68) sebanyak $18 \mathrm{mg}$. Hasil KLT senyawa $\mathrm{D}_{1}$ (Gambar 3 ) dengan eluen n-heksan:etil asetat (8:2) diperoleh noktah dengan nilai Rf 0,66 dan bila direaksikan dengan anisaldehid memberikan warna biru.

Senyawa $\mathrm{D}_{1}$ berupa amorf putih, sedikit larut dalam etil asetat, sukar larut dalam metanol, praktis tidak larut dalam $n$-heksan serta meleleh pada suhu $280-282^{\circ} \mathrm{C}$. Pemeriksaan senyawa $\mathrm{D}_{1}$ menggunakan pereaksi Lieberman-Bouchard menunjukkan warna orange coklat. Hasil pengukuran spektrum ultraviolet senyawa $\mathrm{D}_{1}$ dengan menggunakan etil asetat memberikan serapan 0,134 pada panjang gelombang 289,5 $\mathrm{nm}$ dan 0,132 pada panjang gelombang 319,5 nm (Gambar 4).

Hasil pengukuran spektrum IR menggunakan $\mathrm{KBr}$ memberikan hasil pada bilangan gelombang $2943 \mathrm{~cm}^{-1}$ terdapat regang gugus $\mathrm{C}-\mathrm{H}$ alifatis yang didukung dengan adanya tekukan $-\mathrm{CH} \mathrm{Sp}{ }_{3}$ pada bilangan gelombang $1454 \mathrm{~cm}^{-1}$, adanya regangan $\mathrm{C}=0$ ditunjukkan pada daerah bilangan gelombang $1687 \mathrm{~cm}^{-1}$, adanya regangan C-O pada bilangan gelombang $1035 \mathrm{~cm}^{-1}$, sedangkan pada bilangan gelombang $1377 \mathrm{~cm}^{-1}$ menunjukkan adanya gugus $-\mathrm{C}(\mathrm{CH} 3) 2$ (geminal dimetil) yang merupakan ciri khas dari senyawa terpenoid (Gambar 5).

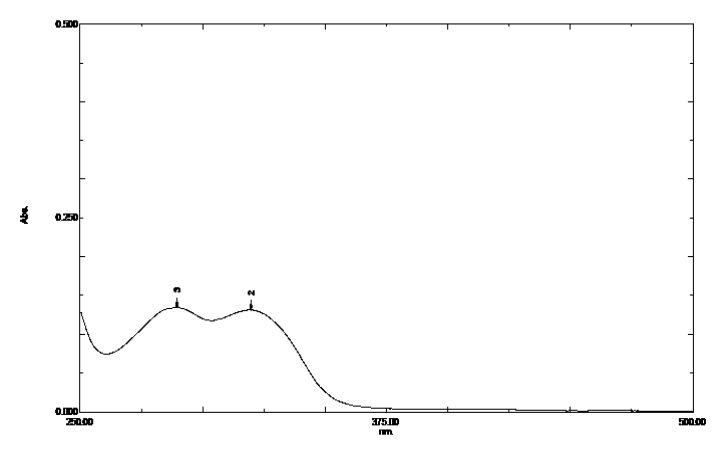

Gambar 4. Spektrum UV senyawa $\mathrm{D}_{1}$

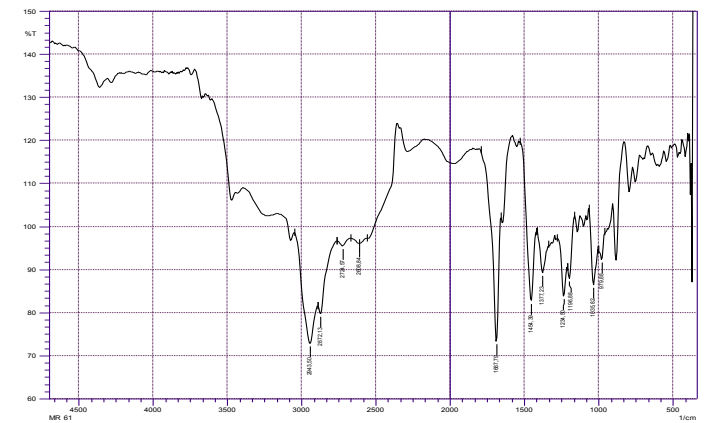

Gambar 5. Spektrum IR senyawa $\mathrm{D}_{1}$

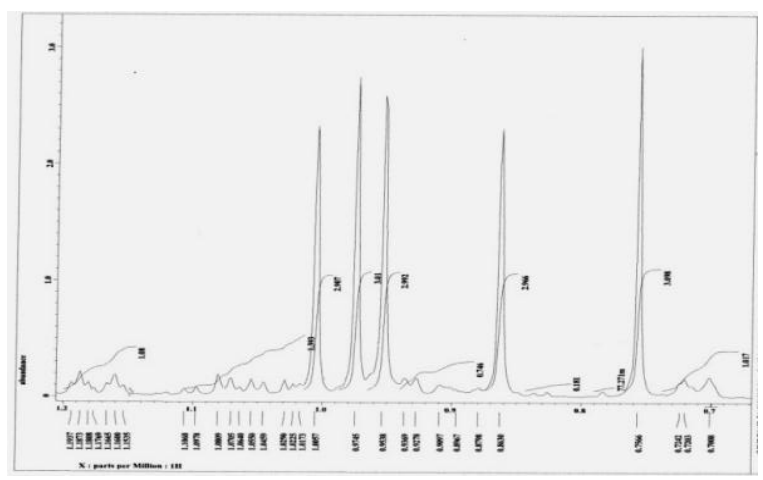

Gambar 6. Spektrum ${ }^{1} \mathrm{H}-\mathrm{RMI}$ senyawa $\mathrm{D}_{1}$ 
Dari spektroskopi ${ }^{1} \mathrm{H}-\mathrm{RMI}$ (Gambar 6) didapat $\mathrm{H}$ metil $\left(\mathrm{CH}_{3}\right) 5$ sinyal singlet dengan intensitas $3 \mathrm{H}$, adanya kelompok sinyal overlapping pada $\delta_{\mathrm{H}} 1,1064-2,0148 \mathrm{ppm}$ dan adanya sinyal double triplet pada $\delta_{\mathrm{H}} 2,2392 \mathrm{ppm}$ dan sinyal triple doublet pada $\delta_{\mathrm{H}} 2,3131 \mathrm{ppm}$. Adanya sinyal multiplet pada $\delta_{H} 3,0136 \mathrm{ppm}$ dan 3,1225 ppm dengan intensitas 1 proton, pada $\delta_{\mathrm{H}} 4,5934 \mathrm{ppm}$ dan 4,7076 ppm terdapat sinyal doublet dengan intensitas 1 proton. Untuk hasil analisa ${ }^{13} \mathrm{C}$-RMI diperoleh sebanyak 30 atom karbon dan kemungkinan senyawa $\mathrm{D}_{1}$ adalah golongan terpenoid.

\section{Pembahasan}

Sampel terlebih dahulu dimaserasi dengan pelarut non polar yaitu n-heksan, selanjutnya ampas dimaserasi kembali menggunakan pelarut semi polar yaitu etil asetat dengan tujuan untuk menyederhanakan komponen kandungan senyawa yang terdapat pada sampel berdasarkan tingkat kepolarannya [10]. Kromatografi kolom terhadap ekstrak etil asetat batang meranti rambai diperoleh hasil pemisahan sebanyak 331 vial. Fraksi yang memiliki profil KLT yang sama kemudian digabung sehingga didapat 16 fraksi gabungan. Fraksi D (vial 60-68) memperlihatkan profil KLT yang bagus dimana terdapat noktah tunggal yang bulat. Fraksi D menunjukkan adanya senyawa amorf berwarna putih kehijauan pada dinding vial.

Pemurnian fraksi D dilakukan dengan pencucian untuk menghilangkan pengotornya. Pencucian dilakukan dengan cara melarutkan senyawa amorf dengan sedikit pelarut yang melarutkannya yaitu etil asetat dan kemudian menambahkan lebih banyak pelarut yang tidak melarutkannya yaitu $n$-heksan. Apabila senyawa amorf sudah mengendap kembali, kemudian dipipet pelarut yang tersisa. Proses pencucian ini dilakukan berulang-ulang sampai didapatkan senyawa murni. Pada proses pencucian ini didapat senyawa berupa amorf berwarna putih yang diberi label $D_{1}$ sebanyak $18 \mathrm{mg}$.
Selanjutnya karakterisasi senyawa $\mathrm{D}_{1}$ dilakukan dengan cara uji titik leleh dan diperoleh nilai titik leleh $280-282^{\circ} \mathrm{C}$. Suatu senyawa dikatakan murni salah satunya apabila selisih harga titik lelehnya kecil atau sama dengan $2^{\circ} \mathrm{C}$. Senyawa $\mathrm{D}_{1}$ dilakukan pemeriksaan secara organoleptis berbentuk kristal yang bewarna putih. Berdasarkan kelarutannya, senyawa ini agak sukar larut dalam etil asetat, sukar larut dalam metanol, dan praktis tidak larut dalam $n$-heksan. Pada pemeriksaan menggunakan pereaksi warna Liebermann-Buchard, senyawa $\mathrm{D}_{1}$ menunjukkan warna orange kecoklatan dan kemungkinan senyawa ini merupakan golongan terpenoid. Pada analisis dengan KLT menggunakan eluen $n$-heksan:etil asetat (8:2), senyawa $D_{1}$ memberikan nilai Rf yaitu 0,66 dan bila diberikan pereaksi anisaldehid memberikan warna biru. Pereaksi warna anisaldehid ini sendiri akan membentuk kompleks sehingga menimbulkan warna yang spesifik dan jelas untuk senyawa-senyawa kimia salah satunya terpenoid.

Senyawa $\mathrm{D}_{1}$ kemudian diuji dengan spektrofotometer UV dan memberikan nilai serapan 0,134 pada panjang gelombang $289,5 \mathrm{~nm}$ yang dirujuk sebagai pita aromatis (benzenoid). Adanya serapan kromofor yang terjadi pada ikatan $n-\pi^{*}$ untuk senyawa karbonil ditunjukkan dengan absorbansi 0,132 pada panjang gelombang $319,5 \mathrm{~nm}$. Hal ini menunjukkan bahwa $\mathrm{D}_{1}$ adalah golongan triterpenoid yang mengandung gugus aromatis yang tersubtitusi dan juga menunjukkan adanya gugus karbonil.

Pengukuran spektrum IR senyawa $\mathrm{D}_{1}$ menggunakan $\mathrm{KBr}$ memberikan serapan pada bilangan gelombang $2943 \mathrm{~cm}^{-1}$ yang merupakan regang gugus $\mathrm{C}$ - $\mathrm{H}$ alifatis yang didukung dengan adanya tekukan $-\mathrm{CH} \mathrm{sp}{ }^{3}$ pada bilangan gelombang $1454 \mathrm{~cm}^{-1}$, adanya regangan $\mathrm{C}=0$ yang ditunjukkan pada daerah bilangan gelombang $1687 \mathrm{~cm}^{-1}$, adanya regangan $\mathrm{C}-\mathrm{O}$ pada bilangan gelombang $1035 \mathrm{~cm}^{-1}$, sedangkan pada bilangan gelombang $1377 \mathrm{~cm}^{-1}$ menunjukkan adanya gugus $-\mathrm{C}\left(\mathrm{CH}_{3}\right)_{2}$ (geminal dimetil) yang merupakan ciri khas dari senyawa terpenoid. 
Karakterisasi lanjutan untuk senyawa $D_{1}$ ini menggunakan spektroskopi Resonansi Magnetik Inti (RMI) yang terdiri dari ${ }^{1} \mathrm{H}$-RMI dan ${ }^{13} \mathrm{C}$-RMI. Spektrum ${ }^{1} \mathrm{H}$-RMI senyawa $\mathrm{D}_{1}$ (dalam $\mathrm{CD}_{3} \mathrm{OD}$ ) diamati pada frekwensi spektrum $500 \mathrm{MHz}$. Pada pergeseran kimia 0,7566; 0,8630;0,9538; 0,9745; 1,057 ppm memperlihatkan adanya 5 sinyal singlet metil $\left(\mathrm{CH}_{3}\right)$ dengan intensitas masing-masing 3 proton. Sinyal ini berasal dari 5 gugus $\mathrm{CH}_{3}$ dengan jumlah atom $\mathrm{H}$ sebanyak 15 . Kemudian pada pergeseran kimia 1,1064-2,0148 ppm menunjukkan adanya kelompok sinyal overlapping yang mengindikasikan sinyal untuk senyawa terpenoid. Untuk pergeseran 2,2392 ppm memperlihatkan adanya sinyal double triplet metine $(\mathrm{CH})$ dengan intensitas 1 proton dengan konstanta kopling sebesar $13 \mathrm{~Hz}(J=13)$. Pada pergeseran kimia 2,3131 ppm menunjukkan adanya sinyal triple doublet metine $(\mathrm{CH})$ dengan intensitas 1 proton dengan konstanta kopling sebesar 11 Hz $(=11)$. Pada pergeseran kimia 3,0136 ppm menunjukkan adanya sinyal multiplet metine (CH) dengan intensitas 1 proton dengan konstanta kopling $11 \mathrm{~Hz}(J=11)$. Pada pergeseran kimia 3,1225 ppm menunjukkan adanya sinyal multiplet metine $(\mathrm{CH})$ dengan intensitas 1 proton dengan konstanta kopling $11 \mathrm{~Hz}(\mathrm{~J}=11)$. Pada pergeseran kimia 4,5934 ppm dan 4,7076 ppm terdapat sinyal doublet dengan intensitas 1 proton. Spektrum ${ }^{13} \mathrm{C}$-RMI senyawa $\mathrm{D}_{1}$ (dalam $\mathrm{CD}_{3} \mathrm{OD}$ ) diamati pada frekwensi spektrum 125 $\mathrm{MHz}$ dan menunjukkan senyawa ini mengandung 30 atom karbon yang muncul dengan pergeseran kimia untuk atom $\mathrm{C}$ metil $\left(\mathrm{CH}_{3}\right)$ adalah $\delta_{\mathrm{C}} 15,21$; 16,$14 ; 16,78 ; 16,78 ; 19,57 ; 19,67 ; 22,22 ; 27,06$; 28,20; dan 28,71 ppm. Untuk pergeseran kimia atom $\mathrm{C}$ metilen $\left(\mathrm{CH}_{2}\right)$ dan $(\mathrm{CH})$ adalah $\delta_{\mathrm{C}} 30,96$; 31,89 ; 33,48; 35,77; 38,22; 38,49; 39,87; 40,06; 40,24; 42,12; 43,74; 49,43; 50,70; 52,18; 57,06; dan 57,64 ppm, pada pergeseran kimia $\delta_{C} 79,86$ ppm terdapat sinyal C-0, pada pergeseran kimia $\delta_{\mathrm{C}} 110,15 \mathrm{ppm}$ terdapat sinyal atom $\mathrm{C}$ benzen, pada pergeseran kimia $\delta_{\mathrm{c}} 152,13 \mathrm{ppm}$ terdapat sinyal untuk karbonil yang terikat dengan asam karboksilat (R-COOH) dan dilanjutkan pada per- geseran kimia $\delta_{C}$ 180,08 ppm terdapat sinyal atom $\mathrm{C}=0$. Sinyal ini bergeser ke arah downfield karena adanya pengaruh atom penarik elektron di sekitarnya [13]. Hasil pembacaan RMI senyawa $\mathrm{D}_{1}$ secara keseluruhan belum dapat disimpulkan struktur lengkapnya, karena masih dibutuhkan data HMBC, HMQC, COZY, dan MS untuk kelengkapan pembacaan struktur senyawa $\mathrm{D}_{1}$ ini.

Hasil uji sitotoksik ekstrak etil asetat kulit batang meranti rambai pada konsentrasi uji 100 $\mu \mathrm{g} / \mathrm{ml}$ menyebabkan kematian hewan percobaan sebesar 93,3\%, $10 \mu \mathrm{g} / \mathrm{ml}$ sebesar 63,3\% dan 1 ppm sebesar $30 \%$. Setelah mengetahui persen kematian kemudian dilihat dalam tabel nilai probit, dari nilai tersebut maka diketahui nilai probit dengan menggunakan persamaan regresi sehingga diperoleh nilai $y=1,0115 x+4,4265 ; r^{2}=0,993$. Maka konsentrasi yang menyebabkan $50 \%$ kematian hewan percobaan (Lethal Concentration, $\mathrm{LC}_{50}$ ) adalah 3,68 $\mu \mathrm{g} / \mathrm{ml}$. Suatu ekstrak dianggap memiliki efek positif terhadap kematian larva Artemia salina jika harga $\mathrm{LC}_{50}$ nya $<1000 \mu \mathrm{g} /$ $\mathrm{ml}$. Disini terlihat bahwa ekstrak etil asetat kulit batang meranti rambai positif sitotoksik atau sangat toksik terhadap larva Artemia salina.

Dari hasil skrining fitokimia ekstrak etil asetat kulit batang meranti rambai mengandung senyawa fenolik dan terpenoid. Efek sitotoksik yang kuat diduga ditimbulkan oleh gabungan dari fenolik dan terpenoid yang ada di dalam ekstrak etil asetat kulit batang meranti rambai tersebut.

\section{Kesimpulan}

Dari penelitian yang telah dilakukan dapat disimpulkan bahwa hasil isolasi ekstrak etil asetat kulit batang meranti rambai diperoleh senyawa D1 sebanyak $18 \mathrm{mg}$ berupa amorf berwarna putih, sedikit larut dalam etil asetat, sukar larut dalam metanol, dan praktis tidak larut dalam $n$ heksan, serta memiliki titik leleh $280-282^{\circ} \mathrm{C}$. Pada pemeriksaan kimia menggunakan pereaksi kimia Liebermann-Buchard, senyawa $\mathrm{D}_{1}$ memberikan warna orange kecoklatan serta didukung dengan data analisis menggunakan spektroskopi UV, IR, 
${ }^{1} \mathrm{H}$-RMI dan memiliki 30 atom karbon pada analisis menggunakan spektroskopi ${ }^{13} \mathrm{C}$-RMI, maka diduga senyawa ini termasuk golongan terpenoid. Dari hasil uji sitotoksik dengan metode Brine Shrimp Lethality Test (BSLT) dapat disimpulkan bahwa ekstrak etil asetat kulit batang meranti rambai memiliki potensi sebagai antikanker dengan nilai $\mathrm{LC}_{50}$ sebesar 3,68 $\mu \mathrm{g} / \mathrm{ml}$.

\section{Daftar Pustaka}

1. Rustaman, Abdurahman M, Jamaludin AA. Skrining fitokimia tumbuhan di kawasan Gunung Kuda Kabupaten Bandung sebagai penelaahan keanekaragaman hayati. Lembaga Penelitian Universitas Padjajaran, Bandung; 2006.

2. Ismarti. Isolasi triterpenoid dan uji antioksidan dari fraksi etil asetat kulit batang meranti merah (Shorea singkawang Miq.). Artikel Pascasarjana Universitas Andalas, Padang; 2011.

3. Norhayati M, Laily BD, Sahidin I, Siti FH, Nazlina I, Zuriati Z, Wan AY. Acuminatol and other antioxidative resveratrol oligomers from the stem bark Shorea acuminata. Molecules. 2012;17(8):90439055.

4. Winata INA, Syah YM, Achmad AS, Hakim EH, Juliawaty LD, Ghisalberti EL, Choudhary MI. Beberapa senyawa stilbenoid dari kulit batang Shorea leprosula Miq. Jurnal Matematika dan Sains. 2003;8(1):23-26.

5. Kusuma R. Analisis ekstrak kulit kayu meranti merah (Shorea leprosula Miq.) sebagai bahan antibakteri terhadap bakteri Escherichia coli. FMIPA Universitas Mulawarman, Samarinda; 2012.

6. Zasliadi A. Isolasi dan karakterisasi senyawa me- tabolit sekunder ekstrak etil asetat daun meranti sabut (Shorea ovalis Kort). Skripsi Sarjana Farmasi; 2013.

7. Sarayobudiyono H, Juliawaty LD, Syah, YM, Achmad SA, Hakim EH, Latip J, Said IM. Oligostilbenoids from Shorea gibbosa and their cytotoxic properties against P-388 cells. J Nat Med. 2008;62(2):195-198.

8. Sahidin S, Hakim EH, Syah YM, Juliawaty LD, Achmad SA, Lajis NHj. Oligomer resveratrol dari kulit batang Shorea assamica Dyer (Dipterocarpaceae) dan sitotoksitasnya. Jurnal Matematika \& Sains. 2007;12(3):113-118.

9. Ashton PS. Dipterocarpaceae, in: Van Steenis CGGJ (Editor). Flora Malesiana, Series 1, Spermatophyta, Vol. 9, Part 2, Martinus Nijhoff, The Hague, Boston, London; 1982, 237-552.

10. Depkes RI. Standarisasi ekstrak. Jakarta: Direktorat Jenderal Pengawasan Obat dan Makanan, Departemen Kesehatan Republik Indonesia; 2000.

11. Watson D. Analisis farmasi: buku ajar untuk mahasiswa farmasi dan praktisi kimia farmasi. Jakarta: EGC; 2009.

12. Creswell CJ, Runquist OA, Campbell MM. Analisis spektrum senyawa organik, terjemahan oleh K. Padmawinata dan I. Soedino. Bandung: ITB; 2005.

13. Silverstein RM, Webster FX, Kiemle D. Spectrometric identification of organic compounds, $7^{\text {th }}$ ed. New York: Jhon Willey and Sons; 2005.

14. Dachriyanus. Analisis struktur senyawa organik secara spektroskopi. Padang: Universitas Andalas Press; 2004.

15. Rohaiza S, Yaacob WA, Din LB, Nazlia I. Cytotoxic oligostilbenes from Shorea hopeifolia. African Journal of Pharmacy and Pharmacology. 2011;5(9):1272-1277. 